\title{
THE INFLUENCE OF INTEGRATED MARKETING COMMUNICATIONS ON THE DEMAND OF SUSTAINABLE PRODUCTS AT LATVIAN FOOD RETAIL CHAINS
}

\author{
Daina Šḳiltere ${ }^{1}$, Santa Bormane ${ }^{2}$
}

\begin{abstract}
Research background: There are a number of product-related tools subject to regulation by state authorities and controlled by subordinate authorities. From the viewpoint of sustainable development, novelties in the legislation, government regulations and other regulatory enactments would enable the state to not only enhance the assortment of sustainable products at food retail chains, but also to raise the awareness of consumers, thus also triggering changes in demand for sustainable (ecological, environment-friendly, high-quality) products. Consumers lack information on the characteristics of the products purchased; they are not knowledgeable about the nutritional value, packaging, raw materials, their impact on human health and environment, re-use and recycling possibilities etc. For instance, the labelling of products may serve not only as a tool of integrated marketing communications drawing the consumers' attention and inciting a purchase, but also - through the information it carries - improve the consumers' knowledge on the product, its nutritional value, use and utilisation. Based on the national legislation and focusing on product-related tools, food retail chains in communication with their consumers may promote and boost the sales of ecological products. The purpose of this article is to assess the influence of product-related tools of integrated marketing communications on product demand at Latvian food retail chains. The subject of the research are product-related IMC tools; and the object of the research are Latvian food retail chains. The research makes use of the results of the study conducted by the authors in 2017. The authors used company data and surveyed leading specialists at Latvian food retail chains. In order to accomplish the goal and objectives, the authors used the following quantitative and qualitative methods of economic research - survey, comparison, and grouping. The study is based on scientific papers published by Latvian and foreign scholars, general and special literature, and periodicals. The authors conducted an assessment, a market investigation, a comparative analysis, held a survey, and used the MS Excel software for data processing and analysis. The findings of the research confirmed the hypothesis that the product-related tools of integrated marketing communications foster demand for sustainable products and, consequently, assortment at retail chains. The results of the research are of both theoretical and practical value.
\end{abstract}

JEL Classification Numbers: M31; DOI: http://dx.doi.org/10.12955/cbup.v6.1195

Keywords: sustainability, sustainable development, sustainable product supply, integrated marketing communications for sustainability; integrated marketing communication tools.

\section{Introduction}

Nowadays, consumers lack information on the characteristics of the products they purchase - their composition, quality; they are not knowledgeable about the nutritional value, packaging, raw materials, their impact on human health and the environment, re-use and recycling possibilities etc. For instance, the labelling of products may serve not only as a tool of integrated marketing communications drawing the consumers' attention and inciting a purchase, but also - through the information it carries - improve the consumers' knowledge about the product, its nutritional value. The purpose of the article is to assess the influence of product-related tools of integrated marketing communications upon product demand at Latvian food retail chains. The subject of the research are product-related IMC tools while the object of the research are Latvian food retail chains. The research makes use of the results of the study conducted by the authors in 2017, company data, a survey of leading specialists from Latvian food retail chains, and MS Excel software which was used for data processing and analysis.

\section{The role of integrated marketing communications in the notification of consumers}

One of the first authors to mention sustainability as one of business innovations with a potential benefit were Boons and Luedeke-Freund (2013) who sought to include perspective business in their research of sustainable innovations. They found that sustainable innovations had so far overlooked four key business management systems and tools: 1) value proposition - what value the product or service offered by the business has; 2) supply chain - how the relationship with suppliers is built, structured and managed; 3) customer interface - how the relationship with customers is streamed, structured and managed; 4) financial model - the costs and benefits resulting from the previous three elements and the mutual interplay of all elements. They maintained that merging the two areas sustainable innovation and business - is beneficial and fosters sustainability. Furthermore, these business tools may be tailored and structured at businesses already in operation. With new businesses,

\footnotetext{
${ }^{1}$ University of Latvia, Faculty of Business, Economics and Management, daina.skiltere@lu.lv

${ }^{2}$ University of Latvia, Faculty of Business, Economics and Management, santa.bormane@gmail.com
} 
systems may be unclear, but may be used as a basis for a plan to move towards lucrative, sustainable activity.

The authors concur and add that value proposition may be directly related to product consumption value, i.e., its quality, ingredients, manufacturing process, sufficient information, necessity, benefits from use, including the utilisation and reuse of packaging. The society of nowadays is interested in consuming sustainable products which are manufactured with an efficient use of resources and the content or use of which does not harm the public's health but rather helps it and contributes to the preservation of the environment and the reuse of waste. (Bormane et al., 2017)

However, the public lacks information. While many product-related tools and attributes are governed by national legislation, the contribution of businesses (incl. manufacturing companies) may still be decisive in providing assortment at shops and, consequently, the consumer's buying choice (Bormane et al., 2018).

Consumers are often confused when having choice. One study found that a message which displayed taste or health on the front of the pack altered consumers' evaluation and choice. The effectiveness of the FOP (taste or health on the front of the pack) message further depended on consumers' health motivation and the healthfulness perception of carrier products (Bialkova et al., 2016). Another piece of research focused on the influence of packaging design upon the buying decision. Data were collected during two field studies in the entrance halls of a discount supermarket visited by price sensitive buyers and a green supermarket frequented by organic buyers respectively. The results from a taste session in which shoppers tasted an identical yoghurt variant from either one of the two package variants revealed that packaging design influenced taste evaluation in the discount supermarket only, with a more healthy packaging appearance positively affecting perceptions of food healthiness (Rompay et al., 2016).

A study with coffee and chocolate as example shows that the perceived quality of the food product is more positive when it is packed in sustainable packaging than when it is packed in conventional packaging (Magnier et al., 2016)

The packaging elements represent a good means of marketing communications towards consumers, because consumers value the elements that are embodied on the package. The information on packaging, too, represents an important component and it can support the marketing communication strategies of companies and establish the brand image and identity. Printed information contains all the information related to the product quality, price, and description, which helps customers identify the product and facilitates the decision process during purchasing (Zekiri \& Hasani, 2015).

Food processing ensures that the resources required to produce raw food materials and ingredients for food manufacturing are used most efficiently. Responding to the goals of sustainability requires the maximum utilisation of all the raw materials produced and the integration of activities throughout the production-to-consumption stages (Floros et al., 2010).

The authors find that the basic conditions for sustainable products are closely related to the information about them available to consumers - environment-friendly product packaging or information about recycling options, design, information on labelling educating consumers about the product, its nutritional value etc. This highlights the role of integrated marketing communications in securing the supply of sustainable products.

According to Praude un Bormane (2012), a successful selling of goods and services requires effective marketing communication in the public to promote cooperation and interaction with buyers and participants of the process of sale of goods and services. This generates feedback with consumers. The primary objective of marketing communications is to arouse the buyer's interest in the product or service. When this has been accomplished, the second stage of marketing communication begins, with the key task of gaining the buyer's loyalty and trust or repeated and regular purchases.

Given the sustainability conditions, food retail chains need to consider what product they will choose and put on shop shelves, whether the product label presents sustainability, not only visually but also informationally, whether the marking and packaging will affect the buyers' behaviour in terms of choosing the product, build an attitude, knowledge on its use and environmental and health impact etc. 
The contemporary integrated marketing communications focus on the consumer and its possible behaviour, rather than on attitudes. Persuit (2013) maintains that behaviour tells more about how a person will act in the future than various intention or attitude approaches. Focussing on consumer behaviour is much more reliable as it enables more precise measurements. Granitz and Forman (2015) claim that content-orientation is characterised by the idea of communication content in the sense of story-telling. Under this IMC approach, businesses are perceived as providers of messages, ideas, stories and subjects topical for customers, i.e. topical in the sense that customers are personally interested in the communication content provided by the company. Certification of sustainable products is mentioned among the possible solutions for promoting a sustainable life style. Sustainable consumption may be fostered by developing and improving the product certification system, informing the buyer of how the product and its manufacturing affects the natural capital. Such a system expands the possibilities for people to participate daily in the promotion of sustainable practice (Latvija2030).

The authors would like to stress the role of consumer-related factors in providing the supply of sustainable products at retail chains since they facilitate the product availability to consumers, as well as the educational information provided by the product, and design which promotes its sales or the consumers' choice of purchase. The authors believe that product-related IMC tools for sustainability also include the proportion of ecological and Latvian-made products that would boost the national economy, supporting domestic production and agriculture. Genetically modified product or product containing genetically modified food ingredients, in turn, have been classified as a separate tool, as consumers need to receive information regarding such type of food on the product so that its consumption be their free, deliberate choice based on information. Under the legislation of the Republic of Latvia, products of such kind are to be placed separately from others, with a special note or informational statement, but in practice businesses tend to disregard this requirement. Hence, consumers are indirectly misled. The proportion of import products, too, is singled out as a key product-related tool for sustainability where businesses might directly, through product assortment and its promotion, adjust the share of Latvian-made products in the overall supply. The proportion of products with environmentally-friendly packaging with quick natural decomposition and the proportion of products with recycled packaging on offer is a key step towards the preservation of the environment. Admittedly, not just the product assortment itself is an essential condition for a change in the public thinking and action in the context of sustainable development, but also the information displayed on the product and the visual layout will have an impact on the buyers' behaviour. This is why such IMC tools for sustainability as product packaging design, information on product labels promoting consumer awareness of sustainability, product healthiness and nutritional value, packaging recycling and utilisation options matter as well. The cooperation between the marketing and procurement departments is crucial, as a sustainable marketing strategy interplays with the procurement strategy in determining the assortment. For instance, when choosing the products to be put on sale, it would be sensible for the procurement department to assess the information carried by the product design, labels and marking, not just for the purpose of sustainability targets, but also from the selling perspective. At self-service retail stores, consumers are sensitive to product appearance, they first "buy with their eyes", so the design and the information carried by the product will not only raise their awareness and competence, but also urge them to buy the particular product. Lastly, an integral part of product-related IMC tools for sustainability is best-before dates on imported and Latvian-made products and the proportions of products with short and long best-before periods in the assortment. The authors hold a view that a short best-before period does not necessarily promote the sales of healthy food without chemicals and preservatives. Consumers will always want to store the purchased products at home for some time, so a very short best-before period also sways their preference towards imported products, which, owing to composition and processing, have a substantially longer best-before period.

On a further note, there is a myth among consumers that a long best-before period implies the presence of chemicals and preservatives which enable keeping products in store for a long time. Consumers believe that the shorter the best-before period, the more natural the product composition. This is another myth which considerably affects sales and necessitates for both the manufacturer and the retailer to communicate with consumers on these matters with a view to raise their awareness, which 
will accordingly generate feedback in terms of sales volumes, recognition, public well-being and Latvia's overall economic development.

\section{A study of the influence of integrated marketing communications on sustainable product assortment}

At the beginning of the article, the authors put forward a hypothesis that product-related IMC tools foster demand for sustainable products and accordingly supply at food retail chains. In order to confirm or reject the hypothesis, in 2017 the authors conducted a survey of leading specialists from Latvian food retail chains. The MS Excel software was used for data processing and analysis.

The leading specialists from Latvian food retail chains were asked to assess the influence of the product-related IMC tools applied by the businesses upon demand, whether the businesses intend to use product-related IMC tools for sustainability in their marketing strategy within the next 3 years, and how their use would affect demand at food retail chains, the economic and social development, and the preservation of the environment, by the following scale: $\mathrm{N}$ - the sustainable marketing communication in question does not exist; -1 - the sustainable marketing communication in question reduces demand, its use will harm the country's economic and social development, the preservation of the environment; 0 - the sustainable marketing communication in question does not affect demand, its use will have no impact upon the country's economic and social development, the preservation of the environment; 1 the sustainable marketing communication in question slightly increases demand, its use will positively affect the country's economic and social development, the preservation of the environment; 2 - the sustainable marketing communication in question substantially increases demand, its use will have a substantial positive impact upon the country's economic and social development, the preservation of the environment. The key deficiencies identified from the survey of leading specialists of Latvian food retail chains served as basis for drafting proposals and improving IMC in the further sustainable development of businesses.

The results of the study and the summary of ratings (see Figure 1) shows that demand is slightly increased by such product-related IMC tools as best-before dates of imported products, proportion of products with a long best-before period in the assortment, proportion of import products on offer, as well as information provided by product marking about product healthiness and nutritional value. Meanwhile, proportion of ecological products on offer, proportion of products with environmentfriendly packaging with quick natural decomposition, proportion of products with recycled packaging and information provided by product marking about packaging recycling and utilisation options are rated as having no effect upon demand. This proves that the product seller or retail chain is interested in reaching sales targets; the lower price when purchasing a high volume of import products with a long best-before period reduces the overall costs associated with the organisation of the selling process, but it aggravates the scarcity of Latvian-made products in stores and facilitates the consumption of products containing preservatives and other chemicals, as the secret behind the long best-before date is a certain chemical treatment destroying natural bacteria which are necessary for the human body but also accelerate the deterioration of products. It is a fact that retail chains do not realise the importance of product composition for human health and the environment, which is why a high proportion of products have a long best-before period. Imported products with a relatively long bestbefore period stifle the sales of Latvian-made products, and the lack of information about the healthiness and nutritional value of products contributes to the deterioration of peoples' health. The results of the survey of leading specialists highlights a current social problem of Latvia - the relatively low availability of ecological products on the shelves of retail chains - and the environmental issues associated not only with the quantity of waste generated by product packaging but also with the relatively low awareness of sellers and consumers on how and where to use products with recycled packaging.

The authors recommend for food retail chains using IMC tools for sustainability to focus not only on short-term sales targets, but also on increasing the share of ecological products in their assortment. The authors find that food retail chains are not the only participant of the selling and delivery process and product manufacturers, too, should get involved in tackling the sustainability issues. Attaching a label with full information about the nutritional value, healthiness, reuse and utilisation of packaging etc. on Latvian-made ecological products with environment-friendly packaging will raise the awareness and competence of consumers, encouraging people towards a sustainable lifestyle. In order to promote the 


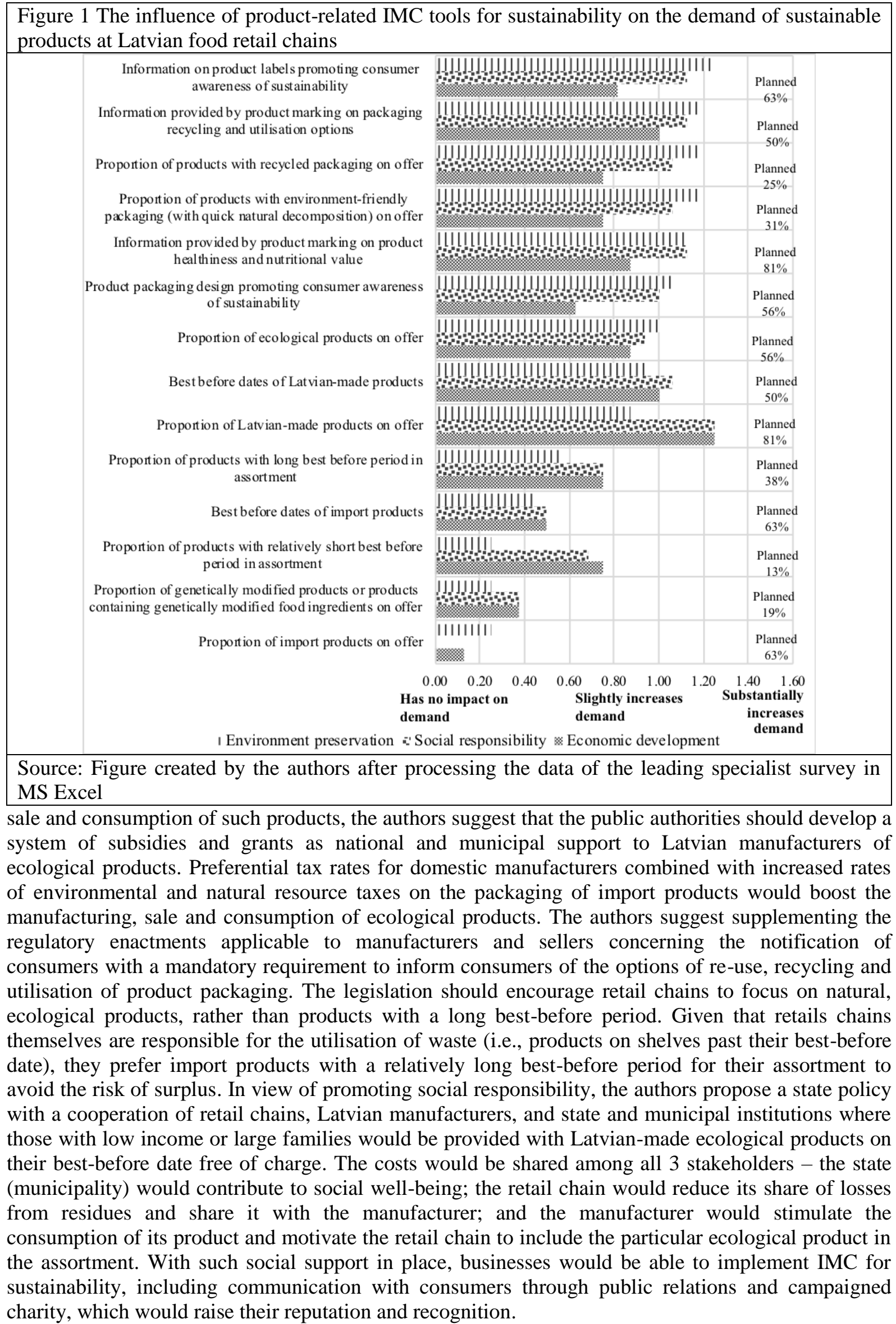

Figure 1 The influence of product-related IMC tools for sustainability on the demand of sustainable products at Latvian food retail chains

Source: Figure created by the authors after processing the data of the leading specialist survey in MS Exce of environmental and natural resource taxes on the packaging of import products would boost the manufacturing, sale and consumption of ecological products. The authors suggest supplementing the regulatory enactments applicable to manufacturers and sellers concerning the notification of consumers with a mandatory requirement to inform consumers of the options of re-use, recycling and utilisation of product packaging. The legislation should encourage retail chains to focus on natural, ecological products, rather than products with a long best-before period. Given that retails chains themselves are responsible for the utilisation of waste (i.e., products on shelves past their best-before date), they prefer import products with a relatively long best-before period for their assortment to avoid the risk of surplus. In view of promoting social responsibility, the authors propose a state policy with a cooperation of retail chains, Latvian manufacturers, and state and municipal institutions where those with low income or large families would be provided with Latvian-made ecological products on (municipality) would contribute to social well-being; the retail chain would reduce its share of losses from residues and share it with the manufacturer; and the manufacturer would stimulate the consumption of its product and motivate the retail chain to include the particular ecological product in sustainability, including communication with consumers through public relations and campaigned charity, which would raise their reputation and recognition. 
This suggests that businesses are willing to invest in raising consumer awareness of sustainability by selecting, e.g., Latvian-made products for their assortment. However, the authors find that it does not only depend on the retail chain that might choose products fostering consumer awareness, the consumption of ecological products, the availability of Latvian-made products etc. It is also the manufacturer's responsibility, and the public authorities, when drafting regulatory enactments, should stipulate a mandatory notification of consumers specifically about the essential issues of sustainability, e.g., how a product may affect people's health, how the product packaging ending up in the environment may or may not affect the protection of the environment, how to utilise it properly etc. of the environment etc.

The authors find that the leading specialists have mixed opinions as to whether the retail chains intend to use products with environment-friendly packaging or recycled packaging in their marketing strategy. This stems from the fact that retail chains are essentially a product seller and the packaging of the product on the shop shelf falls under the direct responsibility of the manufacturer. In order for the manufacturer to package its product in an environment-friendly way, with information to consumers about the importance, use and proper utilisation of environment-friendly packaging, Latvian manufacturers need to have interest and understanding in the problematic matter.

The opinions of the leading specialists also suggest that the retail chains are willing to include such products in their assortment but cannot take full responsibility if there is no such offer from manufacturers. Hence, the authors find that the manufacturers lack understanding of the matter, but it could be enhanced through a regulatory framework, research, publications, reports etc.

As concerns such product-related IMC tools as information provided by product marking about packaging recycling and utilisation options and best-before dates of Latvian-made products, the leading specialists have mixed views, with part of the companies willing to pay attention to these IMC tools and the other part having no intention of using them. The authors see the leading specialists' opinion regarding information provided by product marking about packaging recycling and utilisation as logical because not only the trader, but also the manufacturer is responsible for the information due to be disclosed on the product marking under the Latvian legislation. This further augments the need for public authorities to get involved in the drafting of appropriate legislation stipulating that product marking shall also contain information about the options of packaging recycling and utilisation. Only then, in the authors' opinion, would there appear more educational, high-quality, environment-friendly and healthy products on shelves, marked with exhaustive and instructive information for consumers.

Furthermore, despite the businesses apparently not planning to use such product-related IMC tools for sustainability as a proportion of products with recycled packaging and proportion of products with environment-friendly packaging with quick natural decomposition in their marketing strategy within the next 3 years, the experts have rated these product-related IMC tools for sustainability as conducive to the economy, social responsibility and the environment, with a particularly positive impact upon the preservation of the environment (see Figure 1). This explains the importance of these IMC tools in the sustainable development of businesses, but only the concerted action of all stakeholders - the state, the manufacturer, and the retail chain - could yield a positive result, with consumers not just having access to such products, but demanding them.

In the authors' opinion, product-related IMC tools for sustainability substantially facilitate the exchange of information between the manufacturer and the consumer and are not just informative, but also educational and action-inciting. Consumers lack information about, e.g. the manufacturer and origin of retail chains' own-brand products - the same manufacturer's products identical in terms of composition and quality may be priced differently due the packaging and the manufacturer's brand value. As part of their sales and marketing strategy and striving to cover a broader target audience, shops offer products from the same manufacturer but for different prices, with own-branded products relatively cheaper while the manufacturer-branded products are more expensive. The authors maintain that giving incomplete product information indirectly misleads consumers, leading to distrust and consumers being discouraged from making a purchase. Hence, the authors suggest that the legislation on the notification of consumers should be revised with the inclusion of provisions obliging manufacturers to present complete information about the origin and manufacturer of products, as this would raise consumer awareness and facilitate making educated choices. 
As there is advanced research needed on what conditions and what information makes consumers make purchases and choose sustainable products, the authors have launched an extended study to find out what IMC tools in the context of sustainability affect the buyers' decisions of buying sustainable products in particular.

\section{Conclusions}

Value proposition may be directly related to product consumption value - quality, ingredients, the manufacturing process, sufficient information, including the re-use and utilisation of packaging, the need for products and the benefits from their use etc.

Consumers lack information and competence on product characteristics, which businesses can raise by applying IMC - on packaging, labels, informational marking, thus boosting the consumption of sustainable products.

IMC focuses on the consumer and its possible behaviour. By implementing IMC through messages and stories, businesses may improve the public's understanding of sustainability and expand the opportunities for people to get involved in the promotion of a sustainable lifestyle.

Businesses lack understanding of the importance of domestic and ecological products for sustainable development and the influence of the share of imported products upon human health and natural capital.

Businesses are ready to use IMC tools, which raise consumer awareness of sustainability, in their marketing strategy within the next 3 years as they believe such tools are beneficial to the environment, economy, and social well-being.

The national legislation may be conducive to sustainable development if it applies not only to the product seller or consumer, but also to the manufacturer - a mandatory statement of information on the product, its packaging etc. has a role in building the supply of sustainable products, with both the seller and the manufacturer involved.

There are in-depth studies of consumers needed that would reveal the emergence of a need for sustainable products and the factors in favour of buying sustainable products.

\section{References}

Bialkova, S., Sasse, L., \& Fenko, A. (2016). The role of nutrition labels and advertising claims in altering consumers' evaluation and choice. 96,. Elsevier Ltd., 38-46

Blaits, D. (2004). Mārketings, Rokasgrāmata. Rīga: Apgāds Zvaigzne ABC, 173

Boons, F., \& Ludeke-Freund, F. (2013). Business models for sustainable innovation: state-of-art and steps towards a research agenda. Journal of Cleaner Production, 45, 9-19.

Bormane, S., Batraga, A., \& Šḳiltere, D. (2017). Sustainability: economic, environmental and public issues. Marketing possibilities. Regional formation and development studies, 21-31

Bormane, S., Škiltere, D., \& Batraga, A. (2018). Impact of the regulatory decisions of the Republic of Latvia of sustainable product supply provided by the food retail chains, Regional formation and development studies, 21-35

Egan, J. (2007). Marketing communications. Italy: Rotolito Lombarda, 178

Floros, J., Newsome, R., \& Fisher, W. (2010). Feeding the World Today and Tomorrow: The Importance of Food Science and Technology. Comprehensive Reviews in Food Science and Food Safety, 9, 580.

Foxton, J. (2008). One of the founding partners of Comment UK, Stimulating WOM through Live Experiential Marketing, Riga: Riga unpublished coference materials, 98.

Granitz, N., \& Forman, H. (2015), Building self-brand connections: exploring brand stories through a transmedia perspective. Journal of Brand Management, 22, 38-59.

Latvija2030, http://www.pkc.gov.lv/nap2020/latvija2030, [accessed 08.02.2017]

Magnier, L., Schoormans, J., \& Mugge, R. (2016). Judging a product by its cover: Packaging sustainability and perceptions of quality in food products. Published by Elsevier Ltd., 132-142.

Persuit, J. (2013). Social Media and Integrated Marketing Communication: Arhetorical Approach. Lexington Books, 31

Praude, V., \& Bormane, S. (2012). Influence of Marketing communications on the Processes of consumers' decisions., 7, Regional Formation and Development Studies, 110-113.

Praude, V., \& Šalkovska, J. (2005). Mārketinga komunikācijas. Rīga: Vaidelote, 17.

Rompay, V. T., Deterink, F., \& Fenko, A. (2016). Healthy package, healthy product Effects of packaging design as a function of purchase setting. 53, 84-89.

Zekiri, J., \& Hasani, V. (2015). The role and impact of the packaging effect on consumer buying behaviour. Ecoforum, 4 (1), 232-240. 